\title{
Impartiality in the EU Asylum Procedure
}

\author{
Pieter van Reenen \\ Staff member Immigration and Naturalisation Service, The Netherlands; \\ PhD student at Vrije Universiteit, Amsterdam \\ p.vanreenen@tele2.nl
}

\begin{abstract}
The Asylum Procedures Directive stipulates that asylum applications are examined 'impartially' by the national authorities. This paper explores the meaning of the term impartiality in administrative settings in EU asylum law focussing on three levels: the Common European Asylum System, the administrative organisational level and the level of the individual immigration officer. CEAs does not provide for a definition of impartiality. The article connects impartiality to the right to good administration as in the Charter of Fundamental Rights of the EU. It includes jurisprudence of the Court of Justice of the European Union and the European Court of Human Rights as well as the approach of the EU Ombudsman and EAso in its scope. These sources provide more concrete aspects of impartiality. The article is finalized with recommendations for a code of conduct.
\end{abstract}

\section{Keywords}

CEAS - EU law - impartiality - decision-making - Professional Ethics

\section{Introduction}

The Asylum Procedures Directive requires that asylum applications are examined 'impartially' by the national authorities. ${ }^{1}$ The notion of impartiality is usually linked to the judiciary as a neutral arbiter between contesting parties.

\footnotetext{
* This article is written on his own account. He thanks Prof. mr. T.P. Spijkerboer, dr.mr. A.M. Reneman and mr. M. Kurver for their valuable comments and encouragement.

1 Art. 10(3) sub a, Directive 2013/32/EU.
}

(C) VAN REENEN, 2018 | DOI:10.1163/15718166-12340032

This is an open access article distributed under the terms of the prevailing CC-BY-NC license at the time of publication. 
Using the term in relation to an administrative (asylum) officer raises the question what impartiality means in that context. Research has shown that credibility assessment decisions (which are at the core of most asylum cases) are ultimately subjective. ${ }^{2}$ This paper explores the meaning of the term impartiality in administrative settings in EU asylum law.

The article starts off with introductory remarks on impartiality. The following three paragraphs deal with impartiality within the Common European Asylum System (CEAS), in administrative organisational settings and on the level of the officer respectively. Paragraph six focusses on the EU-Ombudsman and EASO as sources for working impartially. The final paragraph contains a discussion, concluding remarks and recommendations for a code of conduct.

Introductory Remarks on Impartiality

Linguistically, impartiality means: not favouring one party or side more than another; being unprejudiced, unbiased, fair, just, equitable. ${ }^{3}$ These meanings reflect the metaphoric image of Lady Justice: being blindfolded she can only focus on the facts of the case, irrespective of her impressions of the protagonists.

For administrative procedures three levels of impartiality can be distinguished: the legal framework (macro), the organisational (meso) and the individual level (micro). ${ }^{4}$ On macro level, international, European and national policies define norms laid down in treaties and other major legal documents. There are, however, various levels of legislation: international refugee law, European law and national legislation. In times of crises, on all these levels provisional emergency measures may be implemented. Because the rules laid down in these legislative sources are not identical, discrepancies occur. This is partly related to the large margin of appreciation which the EU legislature granted to Member States when implementing the Asylum Procedures Directive (Procedures Directive). ${ }^{5}$ On meso level, relevant issues are whether

2 R. Thomas, 'Assessing the Credibility of Asylum Claims, EU and UK Approaches Examined', 2006 European Journal of Migration and Law 8: 79-96.

3 Oxford English Dictionary, www.oed.com (accessed 1 October 2016).

4 L. Meuleman, Public Management and the Metagovernance of Hierarchies, Networks and Markets; the Feasability of Designing and Managing Governance Style Combinations, Heidelberg: Physica-Verlag 2008, pp. 10, 11.

5 Recital 11 and Article 23, Directive 2005/85/EC. CJEU, Brahim Samba Diouf v Ministre du Travail, de l'Emploi et de l'Immigration, 28 July 2011, C-69/10, para. 29. CJEU, H.I.D., B.A. v Refugee Applications Commissioner, 31 January 2013, C-175/11, paras. 64, 65. 
the organisation taking asylum decisions should be an independent body or, if it can be part of government bureaucracy, what organisational requirements follow from the notion of impartiality? On micro level, impartiality can be related to external signs (for example: dress), to attitude and expertise. (Macro Level)

CEAS does not contain a definition of impartiality. ${ }^{6}$ Art. 10(3) sub a of the Procedures Directive requires that Member States shall ensure that: 'applications are examined and decisions are taken individually, objectively and impartially'. Initially, impartiality was intended to avoid 'discriminating between similar cases for, inter alia, political reasons.7 Impartiality is an element of the general principle of good administration, which is laid down in Art. 41 of the Charter of Fundamental Rights of the European Union (the Charter). ${ }^{8}$ In CEAS good administration is laid down comprehensively in Chapter 2 of the Procedures Directive. ${ }^{9}$ The travaux préparatoires of the Procedures Directive reveal that two provisions in this chapter are most closely linked to impartiality when dealing with asylum cases: the inclusion of country of origin information from various sources including civil society organisations, ${ }^{10}$ as well as that

6 I have looked through all relevant CEAs documents, down to the courses in the European Training Curriculum that EASO provides for immigration officers at: https://training .easo.europa.eu/lms/ (limited access). This includes the Proposal for a Regulation of the European Parliament and of the Council, establishing a common procedure for international protection in the Union and repealing Directive 2013/32/EU, Brussels, 13.7.2016, Сом (2016) 467 final; 2016/0224 (COD).

7 Explanation on Art. 6: Explanatory memorandum, a supplement to the Proposal for a Council Directive on minimum standards on procedures in Member States for granting and withdrawing refugee status, $\operatorname{COM}(2000) 578$ final, OJ C 62, 27.2.2001; http://eur-lex .europa.eu/legal-content/EN/TXT/?uri= CELEX:52000PC0578 (accessed 1 March 2018).

8 Although the CJEU has ruled that this article is not applicable to asylum cases, the right to good administration as a general principle of EU law is. Directive 2013/32/EU, Recital 60. CJEu, H.N. v Minister for Justice, Equality and Law Reform, Ireland, 8 May 2014, C-604/12, para. 49. CJEu, Mukarubega $v$ Préfet de police, Préfet de la Seine-Saint-Denis, 5 November 2014, C-166/13, paras. 42-45. Recital 30 of the proposal for a new Asylum Procedures Regulation: $\operatorname{COM}(2016) 467$ final; 2016/0224 (COD).

9 Opinion of Advocate General Bot in H.N.v Minister for Justice, Equality and Law Reform, 7 November 2013, C-604/12, para. 64 .

10 Art. 10(3) sub b, Directive 2013/32/EU; European Parliament, Committee on Legal Affairs, 2000/ 0238(CNS), AD $\backslash 571004 \mathrm{EN}$, Amendment 25, www.europarl.europa.eu. A bit similar in: Recital 30, Proposal for a Regulation of the European Parliament and of the Council, 
the Member States should ensure that the person who conducts the interview on the substance of an asylum application should not be wearing a military or law enforcement uniform. ${ }^{11}$ Uniformed staff could 'generate confusion on the part of the applicant as to the exact function of the interviewer and undermine the sense of confidentiality and impartiality which is vital if the interview is to proceed smoothly'. ${ }^{12}$ Both issues stress the importance of impartiality as a central requirement for the applicant's confidence in asylum procedures.

Article 4(1) of the Qualification Directive obliges the examining authority to assess the application in cooperation with the applicant. ${ }^{13}$ Chapter 2 and 3 of the Procedures Directive specify what is entailed by this duty. ${ }^{14}$ It implies that the two parties work together towards a common goal: assessing whether the fear of persecution is objectively justified. ${ }^{15}$ This duty addresses the mindset of the officer: she should not adopt an adversarial attitude nor should she position herself as a state-representative defending political goals focussed on national interests. ${ }^{16}$ In the context of the right to be heard this requires an officer ensuring a sphere of trust, enabling the applicant 'to state his case clearly and give full expression to his opinions and feelings. ${ }^{17}$ This is where the prohibition of uniform-wearing fits in: to ensure this sphere of trust, the officer should display impartiality in clothing as asylum seekers may have faced negative experiences with (uniformed) authorities in their countries. ${ }^{18}$

The duty to cooperate also covers the issue whether the administration should investigate on its own motion relevant elements. ${ }^{19}$ This is yet another point where the required non-adversarial nature of the assessment of the asylum application has concrete effects. The Court of Justice of the European

establishing a common procedure for international protection in the Union and repealing Directive 2013/32/EU, Brussels, 13.7.2016, СОм(2016) 467 final; 2016/0224 (COD).

11 Art. 15(3) sub d, Directive 2013/32/EU.

12 Report of the Committee: A7-0085/2011 (24 March 2011), Amendment 81; Resolution EP: P7_TA(2011)0136 (6 April 2011); OJ C-296 E/184.

13 Directive 2011/95/EU.

14 Opinion of Advocate General Bot, M.M. v Minister for Justice, Equality and Law Reform, C-277/11, 26 April 2012, para. 22.

15 Ibid., paras. 55, 59 .

16 This can be deduced from paras. 195-205 of the UNHCR, Handbook and Guidelines on Procedures and Criteria for Determining Refugee Status under the 1951 Convention and the 1967 Protocol Relating to the Status of Refugees, Geneva: UNHCR 2011, to which AG Bot of the CJEU refers in: Opinion of Advocate General Bot, Case C-277/11, M.M. v Minister for Justice, Equality and Law Reform, 26 April 2012, paras. 66 and 67.

17 Opinion of Advocate General Bot, Case C-277/11, M.M. v Minister for Justice, Equality and Law Reform, 26 April 2012, paras. 48, 51 .

18 Ibid., para. 66.

19 UNHCR 2011, para. 196. 
Union (the Court) has ruled that it may be necessary to examine matters not expressly raised by the complainant as part of its obligation to deal diligently and impartially with its inquiry, ${ }^{20}$ sometimes culminating in cases where the applicant is overruled in his application for subsidiary protection where the administration finds a refugee status more appropriate..$^{21}$

To round off, impartiality on macro level is anchored in the right to good administration. For asylum cases it is worked out in Art. 4(1) Qualification Directive in conjunction with Chapters 2 and 3 Procedures Directive. Member States have to take a non-adversarial position and be particularly sensitive to political tendencies in the asylum process, as a peril for impartial decisionmaking. However, the Procedures Directive nor the Charter provide for a clear definition of impartiality. Concrete requirements following from the element impartiality are:

- Inclusion of country of origin information from various sources including civil society organisations;

- Staff members who conduct interviews on the substance of asylum applications should not wear military or law enforcement uniforms;

- The administration should investigate on its own motion relevant elements, i.e. by eliciting all such views as may be necessary;

- The administration may overrule the asylum seeker in his application for subsidiary protection where it finds a refugee status more appropriate.

Impartiality is also relevant on organisational level: how do national immigration services organise their work to live up to the requisites of CEAs?

In judicial settings, impartiality implies standing above conflicting parties, ensuring a level playing field for the parties involved. ${ }^{22}$ Dealing with the definition of a national court or tribunal within the meaning of Article 234 EC, the Court in Wilson presented its comprehensive view on independence and impartiality in judicial settings. In her opinion on Wilson, AG Stix-Hackl stated

\footnotetext{
20 CJEU, Commission v Sytraval and Brink's France, 2 April 1998, C-367/95, para. 62.

21 CJEu, H.N. v Minister for Justice, Equality and Law Reform, 8 May 2014, C-604/12, para. 34, in conjunction with Opinion of Advocate General Bot, H.N. v Minister for Justice, Equality and Law Reform, 7 November 2013, C-604/12, paras. 49, 56, 57. See also: Opinion of Advocate General Bot, M.M. v Minister for Justice, Equality and Law Reform, 26 April 2012, C-277/11, para. 65 .

22 CJEU, Wilson v Ordre des avocats du barreau de Luxembourg, 19 September 2006, C-506/04, paras. 51,52 .
} 
that independence 'is perhaps the most important distinction between national courts and administrative authorities. ${ }^{23}$ The Court phrased it thus: independence involves primarily 'an authority acting as a third party in relation to the authority which adopted the contested decision. ${ }^{24}$ This does not prescribe a theoretical concept regarding the permissible limits of the powers' interaction, but, according to the Court, requires the imposition of practical rules regarding the composition of the body and the appointment, length of service and the grounds for abstention, rejection and dismissal of its members. ${ }^{25}$ ECtHR case law adds expressly the existence of guarantees against outside pressures ${ }^{26}$ or interventions for instance to maintain good international relations of other political interests. ${ }^{27}$ In the end the relevant issue is whether Member States legislation provides for an effective, sufficiently independent, remedy. ${ }^{28}$

Transferring this definition to administrative settings is not easy. Should the organisation which examines the asylum application independently weigh the interests of the state versus those of the applicant? The Member States when negotiating CEAS in an early stage did not embrace organisational independence as a formal requisite for administrative impartiality. ${ }^{29}$ Art. 2 (f) and 4 of the Procedures Directive leave the issue of independence of the determining authorities as an option to the Member States. In practice, Member States opt for wide divergent arrangements, some focussing on organisational, others on individual level. ${ }^{30}$ Still, irrespective of the form of (in)dependence, the

23 Opinion of Advocate General Stix-Hackl, Wilson, 11 May 2006, C-506/04, para. 45.

24 CJEU, Wilson v Ordre des avocats du barreau de Luxembourg, 19 September 2006, C-506/04, para. 49. CJEU, Corbiau v Administration des Contributions du Grand-Duché de Luxembourg, 30 March 1993, C-24/92, para. 15 .

25 CJEU, H.I.D. v Ireland, 31 January 2013, C-175/11, paras. 88 and 97.

26 ECtHR, Kleyn and others $v$ the Netherlands, 6 May 2003, appl. no. 39343/98, 39651/98, $3147 / 98$ and $46664 / 99$, para. 190.

27 ECtHR, A.D. and others $v$ Turkey, 22 July 2014, appl. no. 22681/o9, para. 101.

28 ECtHR, Ramsahai and others $v$ The Netherlands, 8 September 1999, appl. no. 52391/99, para. 302. ECtHR, Bryan $v$ the United Kingdom, 22 November 1995, appl. no. 19178/91, para. 40.

29 Mr Doede Ackers, author of the proposal for the Procedures Directive, by email to the author, 8 April 2015 .

30 Varieties are for instance: the Dutch Immigration and Immigration Service is directly accountable to the State Secretary, a politician, whereas the Belgian Commissioner General for Refugees and Stateless Persons (CGRS) is a fully independent body; http://www .cgvs.be/sites/default/files/brochures/2012_asiel-in-belgie_eng.pdf (accessed: 8 March 2018). Likewise, until 31 December 2016: the Irish Office of the Refugee Applications Commissioner (Refugee Act, 1996, Art. 6.). The present Irish International Protection Act 2015 contains no organisational independence clause, but Art. 74(4) reads: 'An 
administrative body cannot stand above conflicting parties like the judiciary, because it lacks the strongly entrenched judicial independence. Case law on independence is relevant, however, as it contains an internal element which:

... is linked to impartiality and seeks to ensure a level playing field for the parties to the proceedings and their respective interests with regard to the subject-matter of those proceedings. That aspect requires objectivity (...) and the absence of any interest in the outcome of the proceedings apart from the strict application of the rule of law. (Emphases added) ${ }^{31}$

In Ziegler, the Court applied its (ECtHR inspired) views on impartiality in judicial settings most specifically to administrative settings and good administration:

Article 41 of the Charter provides that every person has the right, inter alia, to have his or her affairs handled impartially by the institutions of the European Union. That requirement of impartiality encompasses, on the one hand, subjective impartiality, in so far as no member of the institution concerned who is responsible for the matter may show bias or personal prejudice, and, on the other hand, objective impartiality, in so far as there must be sufficient guarantees to exclude any legitimate doubt as to bias on the part of the institution concerned. (Emphases added) ${ }^{32}$

The ECtHR has added that objectively justified appearances of a certain importance, in the eyes of the public as well as in the eyes of parties to the procedure, may raise doubt as to subjective or objective impartiality of the administrative body. ${ }^{33}$ Potentially relevant for administrative settings is case law on judges who have been involved in pre-trial measures. According to the ECtHR the extent and nature of the pre-trial measures taken by the judge could raise an

international protection officer shall be independent in the performance of his or her functions', http://www.irishstatutebook.ie/eli/2015/act/66/enacted/en/print (accessed 13 January 2018).

CJEU, Wilson v Ordre des avocats du barreau de Luxembourg, 19 September 2006, C-506/04, paras. 51,52 . Commission of the European Union, Commission Staff Working Document, 21 October 2009, (SEC(2009) 1376 (part I), p. 121, footnote 43).

32 CJEU, Ziegler SA v Commission, 11 July 2013, C-439/11 P, para. 155. The Court refers to its earlier case law including ECtHR jurisprudence: CJEU, Chronopost and La Poste $v$ UFEX and Others, 1 July 2008, joined Cases C-341/06 P and C-342/o6 P, para. 54, and CJE U, Gorostiaga Atxalandabaso $v$ Parliament, 19 February 2009, C-308/07 P, para. 46.

ECtHR, Fey v Austria, 24 February 1993, appl. no. 14396/88, para. 30. 
issue about his impartiality. ${ }^{34}$ The mere fact that a judge has made pre-trial decisions does not in itself justify fears as to his impartiality. ${ }^{35}$ However, if a judge had been involved in adverse decisions i.e. versus the accused, there could be 'genuine doubt' as to the judge's impartiality. ${ }^{36}$ This is also the case when the judge has wide-ranging powers during a secret preparatory investigation: it may create 'unease' about the judge's impartiality when sitting in court. Relevant is also that it is 'conceivable' that this judge has more knowledge than his colleagues, thus playing a 'crucial role in the trial court' and may even 'have a pre-formed opinion which is liable to weigh heavily in the balance at the moment of the decision. In addition, the criminal court (...) may (...) have to review the lawfulness of measures taken or ordered by the investigating judge.'. ${ }^{37}$ The Court concedes that this situation provides grounds for legitimate misgivings about the impartiality of the judge.

The Sheridan case applies to administrative settings: the complainant challenges the impartiality of a job selection committee. The Court finds it worth noting that this committee consists of three members, of various capacity, which is unanimous in its decision. ${ }^{38}$ Implicitly, the Court, by noting the size and diversity of the committee, includes a variant of inter-subjectivity as a relevant element in her judgement on impartial handling.

We can conclude that organisational independence is crucial for impartiality of the judiciary, but is not required of the administration. On other points, however, impartiality on meso level is not essentially different in judicial and administrative settings. Impartiality requires administrative bodies to supply in its organisational structure sufficient guarantees to exclude any legitimate doubt as to its impartiality, for instance by organising inter-subjectivity. The caution in judicial settings when a judge has been involved in earlier stages of the case is particularly relevant for administrative bodies. This issue, at the intersection of meso and micro level, will be addressed below.

\footnotetext{
34 ECtHR, D.N. $v$ Switzerland, 29 March 2001, appl. no. 27154/95, para. 53.

35 ECtHR, Fey v Austria, 24 February 1993, appl. no. 14396/88, para. 28. ECtHR, Castillo Algar $\nu$ Spain, 28 October 1998, (79/1997/863/1074), para. 48.

36 ECtHR, Castillo Algarv Spain, 28 October 1998, (79/1997/863/1074), para. 49.

37 ECtHR, De Cubber v Belgium, 26 October 1984, appl. no. 9186/80, paras. 29, 30.

38 CJEU, Sheridan $v$ European Foundation for the Improvement of Living and Working Conditions, 15 February 1996, T-589/93, paras. 107, 108.
} 


\section{$5 \quad$ The Position of the Immigration Officer (Micro Level)}

Asylum officers often apply their most powerful but at the same time most controversial instrument in credibility assessment: intuition or 'professional' instinct. ${ }^{39}$ This is usually based on shared experiences amongst the officers and focusses on the question: 'what would I, or people I know, do in this situation?'40 Irrespective of the legal framework, these circumstances lead to Thomas' observation referring to UK case law: 'What decision-makers ultimately make of the material presented to them is a matter for their own conscientious judgment'.11 This creates wide margins for subjective decisionmaking. In its best form this allows for the flexibility which is necessary in a

39 O. Jubany, 'Constructing truths in a culture of disbelief. Understanding asylum screening from within', 2011 International Sociology 26(1): 74-94, at 86; M. Kagan, 'Is truth in the eye of the beholder? Objective credibility assessment in refugee status determination', 20022003 Georgetown Immigration Law Journal 367, 17(3): 367-415, at 374-377; P.A. Granhag, L. Strömwall \& M. Hartwig, 'Granting Asylum or Not? Migration Board Personnel's Beliefs about Deception', 2005Journal of Ethnic and Migration Studies 31(1): 29-50, at 46.

40 J. Herlihy, K. Gleeson \& S. Turner, 'What Assumptions about Human Behaviour Underlie Asylum Judgments?', 2010 International Journal of Refugee Law 22(3): 351-366, at 352, 358. Stronger criticism in: J. Millbank, 'The Ring of Truth: A Case Study of Credibility Assessment in Particular Social Group Refugee Determinations', 2009 International Journal of Refugee Law 21(1): 1-33, at 21; Amnesty International, Get it Right: How Home Office Decision Making Fails Refugees, London: Amnesty International 2004, p. 23.

41 R. Thomas, 'Assessing the Credibility of Asylum Claims, EU and UK Approaches Examined', 2006 European Journal of Migration and Law 8: 79-96, at 86. Similar conclusions in: R. Thomas, 'Consistency in Asylum Adjudication: Country Guidance and the Asylum Process in the United Kingdom', 2008 International Journal of Refugee Law 20(4): 489-532, at 491, 532; M. Kagan, 'Is truth in the eye of the beholder? Objective credibility assessment in refugee status determination', 2002-2003 Georgetown Immigration Law Journal 367, 17(3): 367-415, at 380; A. Glass, 'Subjectivity and Refugee Fact-Finding', in: J. McAdam (Ed.), Forced Migration, Human Rights and Security, Oxford: Bloomsburg Publishing PLC 2008, p. 213; J. Herlihy \& S.W. Turner, 'The Psychology of Seeking Protection', 2009 International Journal of Refugee Law 21(2): 171-192, at 189, 190; E.C. Barry-Murphy \& M.O. Stephenson Jr, 'Recognizing and Confronting State Subjectivity in Asylum Adjudications, 2015 Refuge 31(2): 3-13, at 8; A. Macklin, Truth and Consequences: Credibility Determination in the Refugee Context, Conference paper, Haarlem: Association Internationale des Juges aux Affaires des Réfugiés 1998, p. 137; J. Millbank, 'The Ring of Truth: A Case Study of Credibility Assessment in Particular Social Group Refugee Determinations', 2009 International Journal of Refugee Law 21(1): 1-33, at 10. 
context where evidence is lacking on crucial points, but in its worst form it may result in a general culture of disbelief ${ }^{42}$ or lottery. ${ }^{43}$

Art. 10(3) sub a, Procedures Directive requires individual, objective and impartial decision-making. It is complex if not impossible to formulate requirements for an impartial mindset as the necessary repertoire includes complicated notions as bias, and cultural and psychological aspects. ${ }^{44}$ The difficulty of pinpointing lack of impartiality on micro level is reflected in case law of the ECtHR when it holds that 'in some cases where it may be difficult to procure evidence with which to rebut the presumption of the judge's subjective impartiality, the requirement of objective impartiality provides a further important guarantee. ${ }^{45}$ The threshold for assuming subjective partiality is rather high: the ECtHR has ruled that the personal impartiality of a judge must be presumed until there is proof to the contrary. ${ }^{46}$ There is no record of an equivalent standard for administrative officers. This may be caused by the fact that organisational independence is not a requisite for administrative settings. Another difference with judicial impartiality is that the Court does not require the administration to take 'sufficient guarantees to exclude any legitimate doubt as to bias on the level of subjective impartiality'. ${ }^{47}$ Possibly, this accounts for the scarcity of Luxembourg and Strasbourg case law on subjective impartiality in administrative settings.

Given the wide margins of subjectivity in decision-making, combined with the lack of requisites directed at organisational level to take sufficient guarantees to avoid bias on micro level, the restraint on involvement of one person in

42 O. Jubany, 'Constructing truths in a culture of disbelief. Understanding asylum screening from within', 2011 International Sociology 26(1): 74-94; C. Rousseau, F. Crépeau, P. Foxen \& F. Houle, 'The Complexity of Determining Refugeehood: A Multidisciplinary Analysis of the Decision-making Process of the Canadian Immigration and Refugee Board', 2002 Journal of Refugee Studies 15(1): 43-70, at 50, 66; Amnesty International, Get it Right: How Home Office Decision Making Fails Refugees, London: Amnesty International 2004, p. 19; T. Butter, Asylum Legal Aid Lawyers' Professional Ethics in Practice, The Hague: Eleven International Publishers 2018, p. 162.

43 Commission of the European Union, Commission Staff Working Document, 21 October 2009, SEC(2009) 1376 (part 1), p. 11, http://ec.europa.eu/smart-regulation/impact/ia_car ried_out/docs/ia_2009/sec_2009_1376_en.pdf (accessed 10 March 2018).

44 UnhCr, Beyond Proof; Credibility Assessment in EU Asylum Systems, Geneva: UnhCR 2013, p. 41; C. Rousseau, F. Crépeau, P. Foxen \& F. Houle, 'The Complexity of Determining Refugeehood: A Multidisciplinary Analysis of the Decision-making Process of the Canadian Immigration and Refugee Board', 2002 Journal of Refugee Studies 15(1): 43-70, at 46 .

45 ECtHR, Morice $v$ France, 23 April 2015, appl. no. 29369/10, para. 75 .

46 ECtHR, Hauschildt v Denmark, 24 May 1989, appl.no. 10486/83, para. 47.

47 CJEU, Ziegler SA v Commission, 11 July 2013, C-439/11 P, para. 155 (quoted above). 
various stages of a procedure or in subsequent applications of one applicant, such as case law requires of judicial bodies, is commendable for administrative setting as well. In this context, the Sheridan case is worth mentioning again, as it offers a variation of multi-staff involvement: the head of service who formerly had written a critical evaluation of his subordinate, figures as a member of a Recruitment Committee for a new vacancy for which this subordinate is a candidate. The subordinate disputes her boss his impartiality in the setting of his membership of the Recruitment Committee because of his previous criticism. The Court considers the allegations not proven as the contested evaluation report is, amongst other arguments, 'reasoned, moderate and free of any element of such a kind as to suggest the existence of any animosity incompatible with the duty of impartiality'48

Recital 17 of the Procedures Directive focusses on micro level as well. It contains as a requirement for working impartially within the framework of the Procedures Directive, that officers should 'perform their activities with due respect for the applicable deontological principles'. These principles were introduced by the European Parliament (EP) during the negotiations with the Commission. ${ }^{49}$ There is no record of who advocated them nor what they imply. Comparing the translations of the language versions of the Procedures Directive, one should understand deontology as: 'ethics. ${ }^{50}$ The German version probably contains the most accurate translation: professional ethical principles ('berufsethischen Grundsätze'). ${ }^{51}$ Mrs Azéma, member of staff of the DG Migration and Home Affairs of the Commission, stated in an email to the author that the sources of these principles are national law and codes of

48 CJEU, Sheridan $v$ European Foundation for the Improvement of Living and Working Conditions, 15 February 1996, T-589/93, paras. 107, 108. The ECtHR considers relevant whether the judge 'had displayed any hostility or ill-will'; in: ECtHR, De Cubberv Belgium, 26 October 1984, appl. no. 9186/80, para. 25.

49 E-mail from Mrs Albine Azéma, DG Migration and Home Affairs, European Commission, 27 July 2015. The EP proposed Recital 15 (a), which is partly amended incorporated as Recital 17 in the Position of the Council at first reading; Position (EU) No. 7/2013 of the Council at first reading (6 June 2013); OJ C 179 E/o2 (25 June 2013).

50 23 language versions of the Procedures Directive are available in EUR-Lex. 14 versions use 'deontology', 9 contain the notion of 'ethical' principles.

$5^{1} \quad$ EU documents on various issues support this translation: Office of the Commissioner General for Refugees and Stateless Persons, Deontology for translations and interpretations, http://www.cgra.be; Directive 2005/29/EC: 'Unfair Commercial Practices Directive', Art. 3(8); EFTA Surveillance Authority Decision, No. 117/14/COL of 12 March 2014, para. 139. Proposal for a Council Regulation (EC) on Community action in the field of statistics (94/C 106/05) (Text with EEA relevance) Сом(94) 78 final-94/oo26(CNS), Art. 9. 
conduct applicable to professions in the field of asylum..$^{52}$ I will not deal with national administrative laws as these should be in accordance with CEAs, but I have looked into a number of national codes of conduct. ${ }^{53} \mathrm{~A}$ few codes contain an, often fragmented, explanation or elaboration on impartiality. Furthermore, there is little concordance between these approaches. Some codes fail to link requisites of impartiality to impartiality. There is no reference to the deontological principles in Recital 17 in any of the codes. The non-discrimination principle (or: same cases treated alike) is often mentioned in relation to impartiality. Avoidance of conflict of interest is mentioned a few times (including variations such as corruption, favouritism or nepotism), as well as avoiding expression of emotion and the prohibition of disparaging remarks, harassment and bullying. The English code is worth quoting as it contains instructions on mindset and decision-making:

Caseworkers must not prejudge the claim or approach the interview with scepticism. They should be aware that their own values, beliefs, prejudices and views, can affect the objectivity of their assessments and should avoid them influencing the conduct of interviews. Issues of credibility will be explored as the interview progresses, but it will not be possible to make a balanced assessment of credibility until all the evidence is considered in the round (...). ${ }^{54}$

One code of conduct elaborates on clothing: interviewing staff should restrain from wearing clothing displaying personal lifestyle, manifesting for instance religious affiliation, as the asylum seeker might feel constrained from relating his asylum motives. ${ }^{55}$

These approaches are worthy of note. Their impact, however, is restricted to the respective countries whereas their legal enforceability is questionable.

All in all, CEAS does not develop a comprehensive approach on impartiality. It does provide a number of elements:

52 E-mail 27 July 2015 from Mrs Albine Azéma, DG Migration and Home Affairs, European Commission to the author.

53 In December 2015 I requested all EU Member States via the European Migration Network for national guidelines or Codes of Conduct focussing specifically on the profession of asylum officer. I received replies from Austria, Belgium, Croatia, Czech Republic, Estonia, Ireland, Latvia, Malta, Norway, Slovakia, Slovenia, and Sweden. I covered The Netherlands myself.

54 Home Office, Asylum Policy Instruction, Asylum Interviews Version 6.o, London: Home Office 2015, p. 12, https://www.gov.uk (Accessed 1 March 2018).

Internal document, available to the author. 
- Inclusion of country of origin information from various sources including civil society organisations;

- Staff members who conduct interviews on the substance of asylum applications should not wear military or law enforcement uniforms;

- The administration should investigate on its own motion relevant elements, i.e. by eliciting all such views as may be necessary;

- The administration may overrule the asylum seeker in his application for subsidiary protection where it finds a refugee status more appropriate;

- The administration should provide for sufficient guarantees to exclude any legitimate doubt as to its impartiality;

- Decision-making should be free from signs of animosity;

- Involvement of more than one person can compensate for doubts about impartiality of one person.

\section{EU Ombudsman and EAso: Inspirational Sources for Professional Ethics?}

The work of the EU Ombudsman centres around The European Code of Good Administrative Behaviour (the Code) as an addendum to Art. 41 Charter ${ }^{56}$ and is considered a source of secondary law. ${ }^{57}$ It is not mentioned in CEAS, ${ }^{58}$ but because the Ombudsman's work addresses Article 41 Charter it may prove to be relevant.

The present Code draws attention to the usage and understanding of 'ethical standards' to bolster an 'administrative culture of service'. These standards are formulated in a list of articles as well as in five 'public service principles' to achieve 'the full and correct application of the Code, of the Charter of Fundamental Rights, and of EU law'. Impartiality is mentioned in various contexts and is connected to objectivity, independence, open-mindedness,

56 European Ombudsman, The European Code of Good Administrative Behaviour, Brussels: European Parliament 2001, www.ombudsman.europa.eu; P. Craig, EU Administrative Law, Oxford: Oxford University Press 2012, p. 344. Also in: S. Peers, T. Hervey, J. Kenner \& A. Ward (Ed.), The EU Charter of Fundamental Rights; a Commentary, Portland, Oregon: Hart Publishing, 2014, p. 1072, 1098.

57 CJEu, Opinion of Advocate General Trstenjak in Koldo Gorostiaga Atxalandabaso, 11 September 2008, C-308/07 P, para. 91.

$5^{8}$ Only the EAso training module on the Procedures Directive (version 3.1, unit 6.1, February 2015) mentions the EU Ombudsman's Code. 
non-discrimination, fairness, reasonableness and the prohibition of preferential treatment on any grounds including national interests. ${ }^{59}$

In her cases and investigations the Ombudsman also refers to EU regulations in which administrative impartiality is mentioned as well as case law of the Court and the ECtHR, even when it concerns impartiality in judicial settings. She also refers to codes and guidelines focussing on specific professional groups or activities. ${ }^{60}$ From these sources she draws her main position on administrative impartiality: 'it is important to avoid not only actual or potential but also apparent conflicts of interest', adding that public trust in the administrative system is vital for the proper functioning of a democracy. ${ }^{61}$ However, she underscores 'that EU public law does not provide a universally accepted definition of conflict of interest or a uniform procedure to address conflicts of interest. The importance of the matter can be hardly overstated'. ${ }^{2}$ The principle of impartiality covers all circumstances which the public might understand to have affected an official's independence when performing his duties. ${ }^{63}$ The absence of a specific definition converges with her overall approach of the right to good administration without compartmentalizing the various elements.

Two cases are illustrative for a second, more concrete, issue which the Ombudsman raises: a faulty sequence in working methods. The Ombudsman: 'It is clearly not good administrative practice to first take a decision and only then to examine the potentially negative consequences it could lead to. ${ }^{\prime 64}$ And: 'By accusing the complainant of abusing the Commission's internal e-mail system and of breaching its contractual obligations before having even launched and carried an investigation into the relevant issues, the Commission failed to

59 European Ombudsman, The European Code of Good Administrative Behaviour, Brussels: European Parliament 2001, p. 9 ('Objectivity'), Art. 8 ('Impartiality and Independence'), Art. 11 ('Fairness'), www.ombudsman.europa.eu.

6o EuropeAid, The Practical Guide to contract procedures for EC external actions of European Commission, in complaints 688/2008/RT and 642/2008 (TS)(ELB)MMN. EULEX Code of Conduct and Discipline, in complaint OI/15/2014/PMC. The Code of Conduct for the Staff of EASA, in complaint 1171/2013/TN. Complaint 539/2012/RA is filed by a former EU election observer: the Ombudsman refers in her decision to (i) the EU Election Observers' handbook, (ii) the EU Election Observers' Code of Conduct[2], (iii) the observers' Terms of Reference, as well as (iv) all instructions issued by the core team.

61 Complaint OI/15/2014/PMC, para. 34. See also complaints 3112/2007/MF, 642/2008/(TS), 1171/2013/TN, 0642/2012/TN, 0297/2013/(RA)FOR, 0476/2010/ANA.

62 Complaint 0476/2010/ANA, para. 89.

63 Complaint 688/2008/RT, para. 21. In this context the vocabulary of the Ombudsman could also apply the use of 'impartiality' instead of 'independence'.

64 Complaint OI/2/2008/(WP)viK, para. 35 . 
demonstrate impartiality vis-à-vis the complainant at this point in time. ${ }^{65}$ This is a useful, although maybe obvious, addition of the Ombudsman to the right to good administration: investigation precedes decision-making. ${ }^{66}$

This approach can also be found in the training module and guideline on decision-making of the European Asylum Support Office (EASO), although they contain no explicit connection to impartiality or reference to Recital 17.67 This material is non-binding. It contains three subsequent steps to avoid premature decision-making: information gathering, credibility assessment and (future) risk assessment.

On information gathering EASO applies the principle of neutrality, which coincides with impartiality as it notes that conflicts of interest, bias or influence of other agendas including policies or guidance considerations of an immigration authority are to be avoided in gathering Country of Origin Information (COI). Neutrality/impartiality also means: using various sources and not looking for information to the (partial) advantage of the decision-maker. ${ }^{68}$ Impartiality of interpreters should be ensured, including the use of 'neutral' linguistic terminology which is particularly important in handling LGBTI cases. ${ }^{69}$

On credibility and risk assessment EAso stresses the need to look in a structural manner at all the issues and evidence in the application 'in the round' for instance by linking evidence to each material fact, assessing sufficiency of detail and consistency in statements also in relation to country of origin information. The result should be a fully reasoned decision weighing the pros and the cons of the application leading to a clear conclusion. Asylum officers should

65 Complaint 2395/2007/vik, First critical remark.

66 Complaint 48/2015/ANA, para. 35 .

67 EAso, European Training Curriculum, Course on Evidence Assessment, at: https:// training.easo.europa.eu/lms/ (limited access); EASO, EASO Practical Guide: Evidence Assessment, Valetta: EASO 2015, https://www.easo.europa.eu. Similar approaches in: UNHCR, Building In Quality; A Manual on Building a High Quality Asylum System, Geneva: UNHCR 2011; UNHCR, Beyond Proof; Credibility Assessment in EU Asylum Systems, Geneva: UNHCR 2013; International Association of Refugee Law Judges (IARLJ), Assessment of Credibility in Refugee and Subsidiary Protection claims under the EU Qualification Directive, Haarlem: IARLJ 2013, http://www.iarlj.org/general/images/stories/Credo/Credo_Paper_ March2013-rev1.pdf (accessed 1 March 2018).

68 The EASO course on Country of Origin Information, contained in the European Training Curriculum, also refers to the training manual of the Austrian Centre for Country of Origin \& Asylum Research and Documentation (ACCORD), https://www.coi-training. net/handbook/Researching-Country-of-Origin-Information-2013-edition-ACCORD-COITraining-manual.pdf, p. 36 (accessed 7 March 2018).

69 EAso, Researching the situation of lesbian, gay, and bisexual persons (LGB) in countries of origin, EASO Practical Guides Series, Valetta: EASO 2015, https://www.easo.europa.eu/. 
keep in mind possible deficiencies of memory function of the applicant, the existence of trauma, the influence of age, education and stress on the ability to state fully one's account. ${ }^{70}$ The interviewing officer should be able to place herself in the shoes of the applicant while keeping emotional distance. The officer should be open-minded by being aware of routine working practices or case hardening, biases, negative culture, stereotyping, compassion fatigue, gut feelings, subjectivity, discrimination etc. The importance of self-evaluation, supervision, feedback and exchange of experience is mentioned as a remedy. Thus, EASO explicitly includes psychological and anthropological insights in its approach. EASO also offers a course for asylum managers in which awareness of most of these issues is addressed. ${ }^{71}$

In conclusion, the Ombudsman requires avoiding actual, potential as well as apparent conflicts of interest, whereas EASO draws attention to specific pitfalls and requirements for asylum staff. Ombudsman and EAso both stress the need to avoid premature decision-making by prescribing that examination is the first step prior to decision-making.

\section{Discussion and Concluding Remarks}

This paper has explored the meaning of the term impartiality in administrative settings in EU asylum law. It has dealt with impartiality on legislative, organisational and individual level (macro, meso and micro level respectively). Overviewing the element impartiality on these levels, the following can be said. The Procedures Directive, by lacking a definition of impartiality, primarily adheres to a normative approach based on linguistic interpretation of the term impartiality. In essence, it requires two aspects of mindset: being open-minded and non-biased. Although formulating an approach on mindset is difficult, one can hardly accept the combination of the element impartiality and the undefined deontological principles as an adequate approach. The procedural requisites in the Procedures Directive and the duty to cooperate in Art. 4(1) of the Qualification Directive do not address mindset directly but operate as assets to working impartially. Specific requirements for meso and micro level follow from case law but, taken together, do not create a comprehensive approach.

\footnotetext{
70 European Asylum Support Office, EASO Practical Guide: Evidence Assessment, Valetta: EASO 2015, https://www.easo.europa.eu.

71 EAso, European Training Curriculum, Module for Managers, Valetta: EAso, https://train ing.easo.europa.eu/lms/ (limited access).
} 
Furthermore, the question is whether asylum staff and organizations feel addressed by the present approach as impartiality is usually associated with the position of a judge or judicial body standing between two contesting parties.

Sociological research shows that at meso as well as at micro level, forms of bias and lack of open-mindedness occur which are not addressed by CEAs's present normative approach and its requirements. Issues compromising impartiality also occur at the intersection of micro and meso level. To name a few: the use of stereotypes and heuristics, ${ }^{72}$ the impact of gut-feeling and intuition, and a negative culture towards asylum-seekers as a form of consensual bias within organisations or working units. ${ }^{73}$

Informal relationships and culture within administrative organisations play an important role in the final outcome of decision-making. ${ }^{74}$ Research into behaviour of international judges points at the large influence of organisational culture, their tendency to vote in favour of their national government, as well as the inclination to avoid being a lone dissenter as illustrative examples of human behaviour in a (judicial) organisation.$^{75}$ These pitfalls, pointing at mindset issues, are crucial for reflection and action on both meso and micro level. The quintessential element here to elaborate on, is impartiality.

The Procedures Directive underrates this powerful impact of mindset on decision-making in asylum cases. Moreover, it provides no safeguards on meso level to cover the pitfalls of mindset. EAso addresses mindset but its material is non-binding. Furthermore, it ignores meso level issues and therefore appropriate remedies on this level. The ECtHR's judgement that objective impartiality (meso level) provides an important guarantee for subjective impartiality (micro level), considering the difficulty of proving subjective impartiality, is therefore not given due attention. ${ }^{76}$

72 J. Herlihy \& S.W Turner, 'The Psychology of Seeking Protection', 2009 International Journal of Refugee Law 21(2): 171-192, at 191; T.S. van Veldhuizen, Where I come from and how I got there; Assessing credibility in asylum cases, dissertation Maastricht University, Enschede: Gildeprint Drukkerijen2017, pp. 50, 51 (ISBN: 978-94-6233-701-5).

73 See note 42. No mention is made of a positive culture towards asylum seekers.

74 T. Havinga, 'Uitvoering tussen ambtenarij en markt', in: R.J.S. Schwitters et al. (Ed.), Recht en samenleving in verandering, Alphen aan de Rijn: Kluwer 2008, pp. 171-200, at 179; P. Mascini, 'Explaining Inequality in the Implementation of Asylum Law', 2008 Refuge: Canada's periodical on refugees 25(2): 168-170; J. Millbank, 'The Ring of Truth: A Case Study of Credibility Assessment in Particular Social Group Refugee Determinations', 2009 International Journal of Refugee Law 21(1): 1-33, at 25 .

75 E. Voeten, 'The Impartiality of International Judges: Evidence from the European Court of Human Rights', 2008 American Political Science Review 102(4): 417-433.

76 ECtHR, Morice v. France, 23 April 2015, appl. no. 29369/10, para. 75. 
Case law, EU Ombudsman, EASO, national codes of conduct as well as professional literature contain practical suggestions to improve impartiality. Various forms of organising inter-subjectivity have been mentioned as essential instrument to focus on mindset: inter-disciplinary (re)training programmes, recruitement of staff focussing on variation in gender, age, prior work, background and culture, multi-staff decision-making, and encouragement of a culture of feedback by supervisory or peer review. In short: creating critical space. ${ }^{77}$ The bounderies of critical space should not be limited to peers, but should include broader organisational levels horizontally and vertically.

To close off, one must acknowledge that a comprehensive enforceable definition of impartiality as a basic principle of mindset is difficult to formulate, given its complexity and overarching impact. Therefore, the non-compartmentalized approach of the EU Ombudsman, embedding impartiality in a broader approach of legal and ethical principles, seems the most viable option. A CEAS code of conduct containing such an approach would be an important practical asset. Increasing awareness of the impact of impartiality in applying asylum law and presenting concrete working methods on meso and micro level should be its prime aim. It should function as a source of secondary law, supplementing Art. 10(3) and the procedural requirements in the Procedures Directive, similar to the Code of the EU Ombudsman in relation to Art. 41 of the Charter. Focussing on, and in addition to, the points in the enumeration in paragraph 5 , the following topics are most prominently recommended covering:

- Focus on avoiding discrimination between similar cases for, inter alia, political reasons by organising critical space within immigration services;

- Discouragement of, or restraint on, involvement of one officer in various stages of a procedure or subsequent procedures of one applicant;

77 F. Crépeau \& D. Nakache, 'Critical Spaces in the Canadian Refugee Determination System: 1989-2002', 2008 International Journal of Refugee Law 20(1): 50-122; J. Ramji-Nogales, A.I. Schoenholtz \& P.G. Schrag, 'Refugee Roulette: Disparities in Asylum Adjudication', 2007 Stanford Law Review 6o: 295-411, at 379; K. Block, D. Warr, L. Gibbs \& E. Gibbs, 'Addressing Ethical and Methodological Challenges in Research with Refugee-background Young People: Reflections from the Field', 2012 Journal of Refugee Studies 26(1): 96-87, at 71; J. Herlihy \& S.W. Turner, 'The Psychology of Seeking Protection', 2009 International Journal of Refugee Law 21(2): 171-192, at 191; J. Millbank, 'The Ring of Truth: A Case Study of Credibility Assessment in Particular Social Group Refugee Determinations', 2009 International Journal of Refugee Law 21(1): 1-33. An example of a helpful test for self-reflection when assessing cases on religious grounds is the Post-Critical Belief Scale: https:// www.kuleuven.be/thomas/p./pkg-pcbs/ (accessed 1 March 2018). 
- Usage of language and terminology, free from signs of animosity, derogation or scepticism in interview settings and decision-making;

- Interviewing staff should restrain from wearing clothing displaying religious or political affiliation or personal lifestyle;

- Applying the structural approach for decision-making as is being offered in EASO materials as a basis for a fully reasoned decision. 